\title{
Liturgiese klere
}

\section{met besondere verwysing na die}

\section{Nederduitsch Hervormde Kerk van Afrika}

\author{
M J du P Beukes \\ Universiteit van Pretoria
}

\begin{abstract}
Liturgical clothes with special reference to the Nederduitsch Hervormde Kerk van Afrika

In the Old Testament it was ruled that church officials should wear special clothes depicting the seperation between God and man. The function of the high priest was fulfilled by Jesus Christ and the gulf between God and man eliminated, making the need for liturgical dress unnecessary îrom the time of the New Testament. Since the earliest centuries of the church, official clothes for clergymen has been uncommon. Although the medieval Roman Catholic Church enforced official liturgical attire, the church reformists viewed such dress with scepticism. It is also considered that in the Hervormde Kerk no liturgical clothes should be worn, other than the academic robe as proof of competence.
\end{abstract}

\section{REI EVANSIE VAN DIE TEMA}

Teologiese studente vra voortdurend na die oorsprong en die prinsipiële verantwoordbaarheid van die bestaan van besondere liturgiese klere vir die predikant in die Nederduitsch Hervormde Kerk van Afrika. Op gemeentelike vlak gebeur dit nog steeds dat aan predikante en kerkraadslede nie die vryheid gelaat word, soos op 
die Algemene Kerkvergadering van 1983 bepaal is, om self te besluit of hulle ' $n$ bef en 'n strikdas wil dra al dan nie. In stryd met die wese van die Hervormde Kerk se kerkregtelike struktuur, neem kerkrade opnuut in dié verband 'n besluit en lê so 'n beperking op individue. Met die oog op die teologies-historiese vraag en die gemeentelike situasie word hierdie studie as noodsaaklik beskou.

\section{METODOLOGIE}

Aangesien die vraag wat op die tafel is, teologies en histories van aard is, het die skrywer gaan kyk na die gegewens soos dit in die Bybel en die geskiedenis voorkom. Die historiese oorsig is breed, omdat daar weinig stof op Afrikaanse bodem oor hierdie tema bestaan.

Nadat die Bybelse en historiese gegewens weergegee is, word gepoog om vanuit daardie gegewens bepaalde afleidings te maak.

\section{BYBELSE GEGEWENS}

In die Ou Testament is die klere wat ampsdraers gedra het, as van besondere belang beskou. God gee nie net self opdrag dat bepaalde klere deur die ampsdraers gedra moet word nie, maar skryf in detail voor hoe hierdie klere moet lyk (Eks 28).

In Eksodus 28 word die ampsdrag wat vir die priesters voorgeskryf is, beskryf. Beide Noth (1959:219) en Fensham (1970:197) oordeel dat dit hier hoofsaaklik gaan om die kleredrag van die hoëpriester. Uit die gegewens van Eksodus 28 en ander Bybelgedeeltes is dit baie moeilik om 'n presiese beeld van die hoëpriester se kleredrag te vorm.

It is hard to understand the individual details in the description of the ceremonial dress of the High Priest for the section is chiefly concerned with him, the ceremonial dress of other priests being dealt with quite briefly in v. 40 not only of the constant recurrence of technical terms whose meaning is uncertain or obscure (from time to time the translation is bound to posit a particular explanation which frequently represents only one possible interpretation), but also because the general appearance of the main items of this dress are presumed to be known and are therefore inadequately described.

(Noth 1959:219)

Noth (1959:220) wys ook op die moontlikheid dat Eksodus 28 die produk kan wees van 'n paar outeurs uit verskillende tye en dat dit daarom hier 'n beskrywing is van 
die hoëpriesterlike drag uit verskillende tye. Hy noem selfs die moontlikheid dat hier sprake kan wees van verskillende ampsdraers se kleredrag.

In vers 6-14 word die (linne skouerkleed) beskryf. Volgens De Wit (1962:326) is die warskynlik die oudste liturgiese drag wat aangetref is. Dit is gedra deur Samuel (1 Sam 2:28), die priesters van Nob (1 Sam 22:19) en deur Dawid toe hy die ark na Jerusalem oorgebring het (2 Sam 6:14). Die Kanaänitiese godin Anat en die Egiptiese priesters het tydens hulle ampsvervulling ook 'n nJy gedra. Dit was die algemene 'ambtsdracht van belangrijke personages, zoals koningen en priesters' (Fensham 1970:198). Die skouerkleed is met twee bande om die skouers vasgemaak. Om die middel is dit met 'n gordel vasgemaak. Twee oniksstene ( $\left(D_{1} \mathbb{H}^{-}\right.$) waarop die name van die twaalf stamme van Israel geskryf is, is op die skouerband van die skouerkleed vasgemaak (Eks 28:9).

Verse 15-30 gee 'n volledige beskrywing van die borsskild of borssak (In). Die borssak is met 'n ryke verskeidenheid materiale en metale versier. Binne die borssak word die Dי borssak is ook die twaalf name van die seuns van Jakob geskryf.

Saam met die skouerkleed word 'n mantel of 'n opperkleed (לעי) gedra. Die מעצ is ' $n$ kleed wat gewoonlik deur konings en hooggeplaastes gedra is (1 Sam 24:5; 1 Kron 15:27; Esra 26:16). Dit was die mees kenmerkende kleed van die "prominenten' (Fensham 1970:200). Die onderste some is versier met granaatjies en goue klokkies wat mekaar afwissel.

Op die voorhoof moet die hoëpriester 'n blom ( $\left.\gamma^{\prime} \checkmark\right)$ op sy tulband dra. Op die ץ' moet staan: 'aan die Here gewy' (Eks 28:36).

Waar die reeds genoemde kleredrag in detail in die Bybel beskryf is, word die onderkleed, die tulband, die gordel en die broek net genoem. Net soos die res van die hoëpriester se klere, is hierdie klere gewoonlik deur konings gedra: 'Ook uit deze tekst blijkt, dat de priesterlijke dracht met de koninklijke samenhangt, hetgeen de hoge staat van de hogepriester accentueert' (Fensham 1970:201).

Die diensklere van die priester was baie eenvoudiger as dié van die hoëpriester. Eersgenoemde se ampsdrag het waarskynlik uit 'n rok (onderkleed of tuniek) van fyn linne, 'n gordel, 'n mus en 'n linnebroek bestaan (Grosheide 1955:397). Die dra van skoene in die tempel was vir die priester en die hoëpriester verbode (Eks 28:4043; 39:27-29).

Die (mantel) is deur die profeet gedra (1 Kon 19:19; 2 Kon 2:8, 13-14; Sag 13:4). Uit Sagaria 13:4 lei Driver (1906:269) af dat die mantel die tipiese drag van die profeet was: 'A mantle was the distinctive garb of a prophet; this passage and 2 K.1:8 show further that it was of hair, whether a sheep's skin, or woven of camel's hair, like that worn by John the Baptist. Here the hairy mantle is in particular a 
mark of the prophet of the degraded professional type referred to above, which had fallen into disrepute.'

In 1 Konings 19:19 word gestel dat Elia sy mantel op Elisa gegooi het. 'De betekenis van de geste is voor Elisa, ook zonder woorden, volkomen duidelijk: dit betekent zijn designatie tot profeet' (Brongers 1967:200). Gray sien in die werp van die mantel meer as net 'designatie tot profeet'. Hy interpreteer die werp van die mantel op Elisa se skouers as 'n 'rite of contactual magic, the mantle, since it was in intimate contact with a man's body, being thought to be imbued with his personality and power' (Gray, in Brongers 1967:201).

Uit 2 Konings 2:8 en 13-14 blyk dat die mantel van die profeet wel besondere 'power' gehad het. Elia het met sy mantel die water gekloof sodat hy en Elisa droogvoets daardeur kon stap. Nadat Elia in die hemel opgeneem is, het Elisa dieselfde met die mantel gedoen. Hierdie gebeure was baie meer as net 'n wonder wat plaasgevind het:

This miracle was intended partly to confirm Elisha's conviction that his petition had been fulfilled, and partly to accredit him in the eyes of the disciples of the prophets and the people generally as the divinely appointed successor of Elijah. All the disciples of the prophets from Jericho saw also from this that the spirit of Elijah rested upon Elisha, and came to meet him to do homage to him as being now their spiritual father and lord.

(Keil \& Delitzsch 1950:297)

Meyers toon vanuit Josua 7:21 en Jona 3:6 aan dat, net soos in die geval van die hoëpriester se klere, die profeet se kleredrag ook groot ooreenstemming getoon het met wat aanvanklik deur veral die koning en hooggeplaastes gedra is (Meyers 1962: 870).

Waarom moes die Ou-Testamentiese profete en priesters besondere klere dra vir hulle dienswerk? Sou daar enige teologiese gronde vir hierdie verskynsel wees? Of het die Israeliete hierdie gebruik van ander volke oorgeneem?

Dit is reeds aangetoon dat dit 'n wyd verspreide verskynsel was dat persone in buitengewone posisies bepaalde klere gedra het en dat hierdie gebruik daarom ook by ander volke voorgekom het. Behalwe hierdie tendens is daar beslis ook teologiese gronde waarom ampsdraers besondere klere moes dra om hulle pligte uit te voer.

Die dra van 'liturgiese klere' was 'n baie ernstige saak. Die priester dra nie bepaalde klere op grond van sy eie besluite nie, maar in opdrag van God self (Eks 28). Hierdie is nie 'n opdrag wat goedskiks oortree kan word en wat ná een geslag sou verval nie. Oortreding van hierdie opdrag het die doodstraf tot gevolg gehad. Dit 
was 'n vaste voorskrif vir die huidige geslag 'en ook vir die wat na hulle kom' (Eks $28: 43 ; 29: 29)$.

As gevolg van die sondeval is die verhouding tussen God en mens verbreek. Die mens is uit die paradys gedryf en het nie meer direkte toegang tot God gehad nie. God het vir die mens die veraf God geword, die God wat agter die voorhangsel funksioneer. Voor hierdie God kon die mens alleen verskyn as God dit goedvind. Uit liefde het God besluit om sy gesprek met die mens voort te sit. Hierdie voortgaande handelinge van God met die mens sou egter plaasvind deur middel van 'n middelaar soos onder andere die profeet en die priester. Dit was die wens van God dat die verteenwoordigers van die volk wat voor Hom verskyn, op 'n bepaalde wyse geklee moes wees (Fensham 1970:201). Die kleding was 'n aanduiding daarvan dat dit God behaag dat juis hierdie persoon voor Hom verskyn. Dit was verder 'n aanduiding van die besondere posisie wat die persoon beklee het.

Die priester het veral 'n baie sterk verteenwoordigende funksie gehad. Die name op die hoëpriesterlike gewaad het gedien om God te herinner dat Hy die twaalf stamme van Israel uitgekies het om sy volk te wees. Net so is die blom op die voorkop van die hoëpriester die teken dat God die volk Israel goedgesind is. Die ampsdrag het veral ook gedien om die volk aan God se heiligheid te herinner.

Die klere van die ampsdraers het buitegewone mag gehad:

The golden bells attached at interva!s between these pomgranates are of apotropaic significance ( $\mathrm{v} 35$ ), as the terrifying effect produced on demons by bells and gongs is an idea widespread in the history of religion. In Ex 28 this effect is still borne well in mind; the ringing of the bells will protec the High priest from the deadly powers of darkness especially when he enters and leaves the sanctuary, as thresholds and doors are particularly threatened by such powers (cf 1 Sam. 5:5).

(Noth 1959:224)

In die Nuwe Testament lyk dit asof ampsdraers steeds die Ou-Testamentiese ainpsdrag gedra het, byvoorbeeld Johannes die Doper wat die mantel gedra het (Matt 3:4; Mark 1:6) en die priesters met hulle besondere klere (Luk 20:46).

In die Nuwe Testament is daar nêrens sprake daarvan dat Jesus Christus enige ampsdrag gedra het nie. Dit lyk selfs of Jesus afwysend gestaan het teenoor ampsdrag (Luk 20:46). Jesus gee aan sy apostels opdrag om die Woord te gaan verkondig sonder enige melding van bepaalde klere wat hulle moet aanhê om dit te doen. Hoewel in die Nuwe Testament op verskillende plekke melding gemaak word van ampswerk wat verrig is en verrig moet word, word nêrens melding gemaak van 'n af- 
sonderlike ampsdrag wat voorgeskryf is nie. Die apostels en ander ampsdraers van die eerste Christelike kerk het waarskynlik met hulle gewone alledaagse klere hulle dienswerk verrig.

Die wegval van besondere liturgiese klere het waarskynlik 'n teologiese agtergrond. Met Jesus Christus se offer aan die kruis is die mens ten volle versoen met God - die toegang na God is weer oop - die voorhangsel van die tempel het geskeur. Die Allerheiligste, die 'woonplek' van God, is nou toeganklik vir alle gelowiges. 'n hoëpriester is nie meer nodig nie. In Jesus Christus is die amp van die hoëpriester vervul. Omdat almal toegang het, is dit nie meer nodig dat 'n hoëpriester met besondere gewyde klere en besondere gewyde aktiwiteite die weg na God vir die gelowige moet open nie.

\section{HISTORIESE VERLOOP}

Tot en met die sesde eeu was daar geen onderskeid in die kleredrag van die ampsdraers en dié van die gewone lidmate nie. Sowel tydens as ná die erediens was die klere van ampsdraers én dié van lidmate dieselfde. Die Apostoliese Constitutiones vermeld in $375 \mathrm{n} \mathrm{C}$ dat ' $\mathrm{n}$ biskop die eucharistie 'clad in splendid raiment' moet gebruik. Dit beteken slegs dat hy aan die Nagmaal met sy 'Sunday best' moet deelneem (Down 1982:347). Volgens Down verwys Christen- en heidenskrywers in hierdie tyd baie na die kleredrag van die biskoppe. Beide groepe skrywers het dit duidelik gestel 'that there was no difference between such dress inside and outside the church, and also that there was no difference between episcopal dress and the dress of laymen. If this is true of the dress of bishops, it is true a fortiori of the dress of the lesser clergy' (Down 1982:347).

In die eerste eeu is die toga vinilis by besondere geleenthede deur die senaat gedra. Sedert die tweede eeu het hierdie besondere drag 'n meer alledaagse drag geword. Die hoër klas het die toga met die linea vervang. Die linea was 'n kledingstuk wat die hele liggaam van nek tot enkels bedek het. Bo-oor hierdie kleed is 'n kort tuniek gedra wat tot op die knieë gehang het. By formele geleenthede het mans en vrouens oor hierdie klere die paenula gedra wat soms lacerna genoem is. Dix (1943: 400 ) verhaal soos volg oor Cyprianus se marteling in $258 \mathrm{n} \mathrm{C}$ :

When he reached the place of execution he took off the red lacerna that he was wearing and folded it and knelt down upon it and prostrated himself in prayer to the Lord. And when he had taken off his tunica and handed it to the deacons, he stood up in his linea and awaited the executioners. These are in essentials the pontificals of a 
medieval bishop. But Cyprian is wearing them simply as the ordinary lay gentleman's dress of the day.

Daar bestaan ' $n$ bekende skets van pous Gregorius die Grote en sy ouers ongeveer $600 \mathrm{n} \mathrm{C}$. Op die oog af is daar geen verskil in die kleredrag van die pous en sy ouers nie. Die enigste verskil is die pallium wat die pous dra. Die pallium is ' $n$ lang serp. Dit is waarskynlik die eerste onderskeidende kledingstuk wat 'n geestelike gedra het. In $425 \mathrm{n} \mathrm{C}$ het pous Celestinus 1 die biskoppe vermaan om nie die pallium te dra nie. Sy woorde word in Engels weergegee deur Down (1982:347): 'We bishops must be distinguished from the people and others by our learning not by our dress, by our life not by our robes.' In $330 \mathrm{n} \mathrm{C}$ het Konstantyn 'n hieran stolen aan die biskop in Jerusalem gegee, om met besondere geleenthede te dra. Op die oog af lyk dit of hier melding gemaak word van spesiale ampsdag. Dit is egter nie die geval nie. Hier word slegs melding gemaak van 'a sumptuous specimen of the ordinary lay costume of the upper classes at this period, not a special hieratic vestment like those of the Old Testament highpriest' (Dix 1943:399).

'Hoewel die pallium sporadies voorgekom het, het dit algemene gebruik in die Middeleeue gebly dat die ampsdraers in gewone klere op straat verskyn het en in gewone klere aan die erediens deelgeneem het. Agter hierdie gebruik om dieselfde klere as die gewone lidmate te dra, het waarskynlik 'n teologiese rede gelê. Die gedagte het sterk geheers dat die gemeente die liggaam van Christus is waarin al die lede gelyk is.

In die tweede eeu het die delmatika in gebruik gekom. Die delmatika is 'n 'form of tunica with large sleeves'. Hierdie kledingstuk is dikwels sonder die linea gedra. Die biskoppe het aan die dra van die linea en die delmatika vasgehou. In die vierde eeu het die diakens van Rome die delmatika begin dra. In die Westerse kerk het dit later die 'distinctive vestment of deacons' geword. In Byzantium het dit die onderskeidende drag van die aartsbiskop geword en in Rusland van alle biskoppe (Dix 1943:402).

Die camelaecum of tiara is ' $n$ hoofbedekking wat in die vierde eeu deur hooggeplaasde staatsamptenare gedra is. Gedurende die vyfde eeu is kerklike ampsdraers ook toegelaat om die camelaecum te dra. Gedurende die Middeleeue het dit algemene drag vir ampsdraers buite die erediens geword. Eers in die elfde eeu is ampsdraers toegelaat om 'n hoofbedekking tydens eredienste te dra en wel in die vorm van die mitre.

In die dae van die Romeinse republiek het groot generaals spesiale campagi of skoene gedra as hulle 'n groot oorwinning behaal het. Hierdie skoene het geleidelik ook die drag van ampsdraers binne en buite die erediens geword. 
Dix (1943:404) som die situasie betreffende klere voor 800 n C soos volg op:

In their adoption there is evidence of a definite policy persued everywhere during the fourth and fith centuries, viz, that the liturgy should be celebrated always in the garments of everyday life. The use of symbolical liturgical vestments like those of the Old Testament priest or the white dress of the neophytes after baptism in the pre-Nicene church was deliberately avoided. The only exception, if it can be called such, was the introduction of the stole; but scarves of office of all kinds were so commonly used in social and civic life in the later fourth century that this too can be brought under the same heading, even though Rome thought otherwise and refused to adopt it for seven centuries or so, exept for the bishop.

What turned this clothing into a special liturgical vesture was mere conservatism. When the dress of layman finally changed in the sixth and seventh centuries to the new barbarian fashions, the clergy as the last representatives of the old civilised tradition retained the old civilised costume.

Volgens Down (1982:348) het ampsdrag geleidelik die kerk binne gekom 'by accident and not by design'.

Gedurende die Middeleeue het die vorm van die ampsdraers se klere voortdurend gewissel. Die lang los klere was egter deurlopend die algemene styl wat kenmerkend was van die ampsdraers se kleredrag. Gedurende hierdie tydperk is by die konsilies nie juis besluite geneem om eenvormigheid ten opsigte van ampsdrag te bewerk nie. Ampsdraers is oor die algemeen toegelaat om volgens eie smaak hulle eie ampsdrag te kies. Dit was 'n algemene tendens dat al die ampsdraers die deftige drag uit die vorige eeue bly dra het. Geleidelik het die afstand tussen ampsdraers en lidmate groter geword. Die ampsdraers het in die laat-Middeleeue 'n selfstandige stand gevorm wat hulleself baie hoër geag het as die sogenaamde leke. Hierdie geestelike hoër stand het op 'n bepaalde stadium selfs hulle eie howe en hulle eie belastingstruktuur gehad. Dit het vir hierdie hoër stand al hoe belangriker geword om van die sogenaamde leke onderskei te kan word, wat hulle in die besonder deur hulle ampsdrag laat realiseer het. 'It was very much in the interest of the clergy to identify their membership of the clerical estate by outward and visible signs, which they did, by the bald crown of the head and a distinctive style of dress' (Down 1982: 349).

Die kleredrag van die ampsdraers het met die verloop van tyd vir die lidmaat die simbool van kerklike hiërargie geword. Wrewel het ontstaan teen die amps- 
draer en sy gewaad. Verset teen die kerklike hiërargie sou daarom ook verset teen die ampsdraer se kleredrag meebring.

Met die aanvang van die Hervorming het die hervormers hulle weinig gesteur aan ampsdrag. Sommige hervormers het sterk daarteen gevoel en sonder meer daarmee weggedoen. Luther het aanvanklik nog die Roomse casula en alt gedra. Toe Karlstadt die hervorming volgens hom te ver voer, het Luther geskryf dat die casula en die alb weer verpligtend behoort te word. Die uiteinde was dat daar nie 'n vaste voorskrif ten opsigte van ampsdrag bestaan het nie. Uit die gegewens beskikbaar lyk dit of sommige ampsdraers voortgegaan het om die Roomse drag te dra en ander geheel en al daarvan afgesien het (White 1980:108-109). Die misgewaad was naderhand feitlik geheel en al afgeskaf totdat dit deur die Leipzig interim in 1548 weer verpligtend gemaak is. Veral in die Saksiese wêreld het dit tot groot verset gelei.

Ten tye van die Hervorming was die koorrok die algemene drag van gegradueerde persone aan universiteite. Die koorrok, ook die priesterrok genoem, het algemene drag geword vir enige persoon wat onderrig gee. Dit was die aanduiding dat die persoon bevoeg is om te onderrig. Luther, Calvyn en ander hervormers word dikwels op sketse en foto's met hierdie rok aangetref.

Luther zelf verscheen den 9 October 1524 het eerst zonder monnikskap in een priesterrok, waarvoor de keurvorst zelf hem de stof had gegeven, in de kerk. 'In diesem Jahre (1524)', lezen wij in Forsters Hgd. vertaling der Centuria Magdenb, 'hat Lutherus der mönischen Hahit abgelegt und im folgenden Zeiten ein Kleid gebraucht, wie ehrbare Personen, so in Predigtampte waren, dazumal zu tragen pflegten.' Dit kleed was in hoofdsaak aan den later priesterrok gelijk.

(Scholten 1856:211)

Die priesterrok het tot in die agtiende eeu die drag gebly wat ampsdraers in Reformatoriese kerke gedra het. Sinodes moes ampsdraers deurlopend waarsku om nie allerlei onnodige versierings aan die priesterrokke toe te voeg nie (Scholten 1856: 213).

Die priesterrok en wat vandag 'toga' genoem word, word sonder meer aan mekaar gelyk gestel.

Luther was feitlik argeloos oor die kwessie van ampsdrag, net soos hy ook was teenoor ander dinge in die kerk, bv. die altare. Toe sy gesag om die Woord te verkondig, later deur Rome betwis is, het hy die akademiese toga van die inrigting waar hy studeer het, aangetrek. Dit het 
gedien as uiterlike bewys van sy bevoegdheid en opleiding om te preek.

(Van Wyk 1983:10)

Veral in Engeland het daar in die sestiende eeu 'n heftige klerestryd ontstaan. Hierdie stryd het in 1550 'n aanvang geneem toe Hooper uit Switserse ballingskap terugkeer en weier om in ampsdrag bevestig te word. Eindelik het hy 'n kompromisvoorstel aanvaar, maar eers nadat hy met veral Bullinger 'n lang korrespondensie gevoer het (Keep 1975:223-230). Bullinger se standpunte het wye inslag gevind. Die aandrang om nog steeds ampsdrag te dra, het hy as 'n nuwe pousdom en 'n 'vestarian bondage' beskryf. Andersyds het hy geoordeel dat ampsdraers nie oor so 'n onbenullige saak soos klere die kerk moet verlaat nie. Die kleredragstryd het nog intenser geword toe aartsbiskop Parker in 1566 sy 'Advertisements' uitgegee het en bepaal het dat sekere ampsdrag in al die Engelse kerke verpligtend moet wees. In Reformatoriese kringe was daar heftige verset en baie ampsdraers het die kerk verlaat. Hierdie kontroversie sou in Engeland bly voortbestaan tot die klerestryd in die agtiende eeu vanself op die agtergrond geraak het.

In die sestiende eeu het die mantel in gebruik gekom. Dit was hoofsaaklik hooggeplaastes wat dit gedra het. In die sewentiende eeu was dit so algemeen dat geen aansienlike persoon daarsonder aangetref is nie. Die mantel was van verskillende soorte materiaal in verskillende kleure gemaak. Die mees algemene mantel was dié wat van swart materiaal gemaak is. Die mantel het geleidelik die drag geword waarin gaste besoek is of waarin hooggeplaastes kerk toe gegaan het (Scholten 1856:221). Die mantel en bef het die kledingstuk geword wat veral deur die Duitse predikant en regsgeleerdes tydens amptelike geleenthede gedra is. Die manel wat later aangetref is, was waarskynlik 'n ontwikkeling uit die mantel.

Die bef wat in die sewentiende eeu algemene drag van alle aansienlike persone geword het, dateer uit die veertiende eeu toe die pous en ander hooggeplaastes begin het om allerlei deftige hempskrae te dra. Volgens Scholten (1856:222) het die bef uit hierdie sierlike hempkrae ontwikkel. Die gebruik het ontstaan om die beffies op allerlei wyses te versier. By verskeie sinodes is teen die versierde beffies besluit. Geleidelik het dit gebruik geword dat sommige predikante in plaas van die koorrok 'n mantel en 'n bef gedra het.

In Suid-Afrika was daar aanvanklik nie sprake van ampsdrag nie (SKLAS 1987: 9). Uit sketse en foto's is dit egter duidelik dat predikante en regsgeleerdes oral in die alledaagse deftige drag met toga of mantel en bef gekleed gegaan het. Sommige foto's toon predikante uit die agtiende eeu met net 'n bef en ander met 'n bef en 'n strikdas (S P Engelbrecht Argief, Pretoria). Aan die begin van die negentiende eeu het Skotse predikante na Suid-Afrika gekom. Dit het meegebring dat die Skotse 
toga en veral die strikdas naas die Hollandse toga met die bef opgemerk is. Die Kerkwette en Bepalings van die Nederduitsch Hervormde Kerk van Zuid-Afrika het voor 1904 reeds bepaal: 'Ieder lid eener kerklijke vergadering moet gekleed zijn in het zwart met witte das. Bij de Algemene Vergadering moeten de predikanten gekleed zijn met mantel en bef (NHKA s j:3). Hoewel die Wette en Bepalings van die Hervormde Kerk tot 1925 aan die predikant die keuse laat om toga of mantel te dra, het die Algemene Vergadering van 1904 reeds aanbeveel dat die predikant 'n toga in plaas van 'n mantel moet dra (NHKA 1904:79). Tot en met die Algemene Kerk Vergadering van 1970 het die predikante van die kerk 'n toga en bef gedra. Sommige predikante het saam met die bef ook nog 'n strikdas gedra. Aangesien die meeste van die Hervormde Kerk se predikante van Holland afkomstig was, was die ou swaar Hollandse toga wat van bo tot onder toeknoop, die algemeenste. Die Vergadering van 1970 het soos volg oor die toga besluit: "Aangesien die toga uitdrukking is van die akademiese bevoegdheid om die evangelie te verkondig en die besondere werk te doen, beveel die vergadering aan dat die toga die akademiese toga sal wees van die plek waar die persoon gestudeer het' (NHKA 1970:103).

Saam met die toga was die bef vir predikante tot 1983 verpligtend. In 1983 besluit die Algemene Vergadering 'dat die dra van 'n bef en strikkie al dan nie, oorgelaat sal word aan die diskresie van die draers' (NHKA 1983:26).

Die gebruik dat ouderlinge en diakens in swart manelpakke met 'n strikdas eredienste en vergaderings bygewoon het, is daaruit te verklaar dat dit in die loop van die vorige eeu die deftige drag van die mans was. Kerkraadslede en lidmate het die eredienste so bygewoon. Toe hierdie vorm van kleredrag vir die algemene publiek verdwyn het, het die kerkraadslede nog aangehou om dit te dra (SKLAS 1987:9). Die manel was tot 1951 verpligtend vir kerkraadslede. Ná 1951 kon dit 'n swart kort baadjie of 'n manel wees (NHKA 1951:168). Die manel het vanself geleidelik verdwyn. Die swart pak is in 1970 vervang met enige donkerkleurige pak: 'Die vergadering bepaal dat ampsdraers ter wille van die netheid en die waardigheid van die vergaderings geklee sal gaan in donkerkleurige pakke met 'n wit strikdas' (NHKA 1970:103). Die strikdas het, soos reeds aangetoon, in 1983 opsioneel geword.

\section{GEVOI GIREKKINGS}

Houda, Dreyer en Muller is van mening dat die kerk geheel en al met ampsdrag moet wegdoen. Houda noem besondere liturgiese drag 'an ambiguous sign'. Volgens hom het klere bepaalde sosiale betekenis. Dit is veral teken van een of ander funksie of status. Vir die gewone mens is dit 'n teken van afstand en wêreldvreemdheid. Die algemene wêreldtendens is om diskriminasie op elke terrein uit te 
skakel. Ampsdrag is 'n teken dat die kerk nog nie ten volle daarin geslaag het om die verskil tussen ampte en leke te oorbrug nie. In baie Reformatoriese kerke word groot klem gelê op die dienswerk waartoe elke lidmaat geroep is. Die handhawing van ampsdrag of besondere drag vir ampsdraers sal beskou kan word as 'n miskenning van dié dienswerk van gewone lidmate (Houda 1991:539).

Net soos Houda oordeel A J G Dreyer in 1970 dat die toga van 'n predikant oorbodig is:

Persoonlik vind ek dit jammer dat die vergadering in die geval nie ook besef het, dat die drag van die predikant maar 'n onbelangrike saak is nie. Gelukkig is dit nie in die wet vasgelê nie. Die tydsverandering het meegebring dat ons hier ook 'n verandering kon aanbring. Die argument dat die toga die bewys is van die predikant se akademiese kwalifikasies mag histories juis wees, maar het in ons tyd geen sin nie. 'n Argitek dra nie 'n besondere soort jas om daarmee aan te dui dat hy as argitek bekwaam is nie. Dieselfde geld vir die ander akademiese opleidings...'n Mens loop nie, en veral nie in die kerk nie, sy akademiese kwalifikasies en rondswaai vir almal om te sien nie.

(Dreyer 1970:9)

Die erediens is 'n kommunikatiewe gebeure. Die kommunikasie is in die eerste plek Woordkommunikasie. Nieverbale kommunikasie speel egter ook 'n belangrike rol. Die atmosfeer wat byvoorbeeld geskep word deur die kerkgebou, die plasing van liturgiese simbole soos die doopvont en die Nagmaaltafel en die kleredrag van die predikant en die kerkraad, dra 'n bepaalde boodskap oor. Hierdie nieverbale kommunikasie kan dit wat die predikant met woorde wil oordra, ondersteun of dwarsboom. Wat word oorgedra deur die swart ampsklere, veral die toga? Volgens Muller (1987:12) skep dit die beeld van somberheid'en wèreldvreemdheid:

Dit is weiklik 'n vraag of die wêreldvreemde kleed van die dominee (wie dra nou in vandag se lewe nog so 'n kleed?) nie medeverantwoordelik daarvoor is dat nie slegs sy persoon nie, maar ook sy boodskap by voorbaat al deur baie afgeskryf word as iets bowêrelds en abstrak, iets wat nie met die gewone dinge van die lewe te doen het nie? Die stywe atmosfeer in ons eredienste, die hoé taalgebruik en die vreemde klere kan maklik die boodskap van God se betrokkenheid by hierdie lewe belemmer.

Teenoor diê negatiewe uitsprake oordeel Cooper dat lidmate in die tradisionele Reformatoriese kerke nooit sal kan aanvaar dat veral die bedienaar van die Woord op die kansel verskyn sonder ' $n$ baie duidelike onderskeidsteken nie. Hy oordeel dat 
die kerk in die hede moet hyk wat ampsdraers in die verlede op die kansel gedra het en in die lig daarvan 'n drag kies wat vir die hede aanvaarbaar sal wees. Die aangewese drag vir die bedien.tar van die Woord sal volgens hom 'n wit alb (tunic), die Geneva gown (toga) en 'n siole (mantel) wees. Cooper gaan so ver om te beweer dat hierdie aanbevelings van hom 'are at the same time biblical, traditional, and distinctly Reformed' (Cooper 1988:35).

By die evaluering van hierdie tema moet die volgende vrae gevra word:

* Is ampsdrag teologies noodsaaklik?

- Kom ampsdrag deurlopend in die geskiedenis voor?

- Is ampsdrag funksioneel?

In hierdie studie is reeds aangetoon dat ampsdrag nie 'n teologiese funksie het nie. Histories gesien het die toga en bef in Reformatoriese kerke by Luther en ander hervormers slegs as aanduiding van akademiese bevoegdheid behoue gebly. Funksioneel het klere 'n breë betekenis: Dit dien as versiering, dit is 'n aanduiding van 'n sekere posisie, status of rykdom, dit dien as beskerming en bedekking en kommunikatief sê dit iets van die draer se opvattings en oortuigings. Die enigste 'amptelike' kerkdrag wat enige funksionele betekenis sou kon hê, is die toga. Dit kan dien as aanduiding van die akademiese prestasie wat die predikant behaal het en is geen ampsdrag nie. As die toga hehou word, moet dit die akademiese toga wees wat die . predikant tydens sy BD-gradeplegtigheid dra. Dit is by hierdie geleentheid wat die graad aan hom toegeken word waarkragtens hy die bevoegdheid het om die Woord te bedien. Dit lyk ook sinvol om slegs die toga aan te trek as hy self die Woord bedien of in 'n amptelike hoedanigheid optree. Geen toga met allerlei versiersels behoort aanvaarbaar te wees nie.

Die bef en die strikdas het hulle oorsprong in die mens se soeke na die estetiese. Op geen stadium het dit enige ander funksie gehad as om mense te laat mooi lyk nie. As sodanig hoort dit nie deel van die predikant of kerkraadslid se besondere kleredrag te wees nie.

Met die oog op orde en sindelikheid sal die kerk altyd kan verwag dat sy ampsdraers so goed as moontlik gekleed sal wees. Die trefkrag van die ampsdraer se bediening lê egter in die bediening van die Woord en nie in allerlei uiterlikhede nie.

In die lig van die besluite van die Algemene Kerkvergadering is dit ook nie meer moontlik vir 'n kerkraad om te besluit dat 'n predikant, behalwe 'n toga, nog iets anders in die vorm van ampsdrag op die kansel moet dra nie. 


\section{Literatuurverwysings}

Brongers, H A 1967. I Koningen. Nijkerk: Callenbach.

Cooper, D J C 1988. Vesture: A reformed perspective. Reformed Liturgy and Music 22, 33-36.

Cope, G 1972. Vestments: A dictionary of liturgy and worship. Davies J G (ed). London: SCM Press.

De Wit, C 1962. The New Bible Dictionary. London: Intervarsity Press.

Dix, D G 1943. The shape of the liturgy. London: Dacre Press.

Down, M 1982. The costume of the clergy. Theology 85, 346-353.

Dreyer, A J G 1970. Besluite van die Algemene Kerkvergadering. Die Henvormer $61 / 5,9$

Driver, S R 1906. The minor prophets: Introductions revised version with notes index and map. Edinburgh: T C Jack.

Fensham, F C 1970. Exodus. Nijkerk: Callenbach.

Grosheide, F W 1955. Bybelse Ensiklopedie. In Afrikaans vertaal deur J H van Wyk.

Kaapstad: Verenigde Protestantse Uitgewers.

Houda, R W 1991. Clerical gab - an ambiguous sign? Worship 56, 537-540.

Keep, D 1975. Bullinger's intervention in the vestiarian controversy 1566. EvQ 47, 223-230.

Keil C F \& Delitzsch F, 1950. The books of the Kings. Grand Rapids: Eerdmans.

Meyers, J M 1962. Dress and ornaments in The Interpreters Dictionary of the Bible. Buttrick G A (ed). New York: Abindon Press.

Muller, J 1987. Huidige ampsdrag wêreldvreemd. Die Kerkbode 24 Junie 1987, 12

Nederduitsch Hervormde Kerk van Afrika s a Wetten \& Bepalingen. Pretoria: NHKA.

--- 1904. Notules Algemene Kerkvergadering. Pretoria: NHKA.

--- 1951. Notules Algemene Kerkvergadering. Pretoria: NHKA.

--- 1970. Notules Algemene Kerkvergadering. Pretoria: NHKA.

--- 1983. Notules Algemene Kerkvergadering. Pretoria: NHKA.

Noth, M 1959. Exodus: A commentary. London: Bloombury Street.

Scholten, G D J 1856. Kerklijke en wereldlijke kleding, de toga, mantel en bef. 's-Gravenhage: Noordendorp.

Sinodale Kommissie vir Leer en Aktuele Sake Ned Geref Kerk Oranje-Vrystaat Sinode (SKI_AS) 1987. Kerklike ampsdrag is 'n vorm van uitgediende mode. Die Kerkbode 23, September 1987, bl 9.

Van Wyk, D J C 1983. Betekenis van amp in inhoud en nie in kleredrag nie. Die Hervormer 75/1, bl 10.

White, J F 1980. Protestant worship, traditions in transition. Kentucky: John Knox. 